Proc. Estonian Acad. Sci. Geol., 1998, 47, 4, 219-228

\title{
CHITINOZOAN BIOFACIES OF LATE EARLY LLANDOVERY (CORONOGRAPTUS CYPHUS) AGE IN THE EAST BALTIC
}

\author{
Viiu NESTOR
}

Institute of Geology at Tallinn Technical University, Estonia pst. 7, 10143 Tallinn, Estonia; e-mail: vnestor@gi.ee

Received 24 October 1997, in revised form 28 November 1997

\begin{abstract}
Four lateral chitinozoan biofacies, mainly defined by the distribution of Cyathochitina species, are recognized from the uppermost lower Llandovery strata (Coronograptus cyphus age) in 18 eastern Baltic sections. Cyathochitina kuckersiana (Eisenack, 1934) seems to have preferred shallow-water near-shore conditions and C. calix (Eisenack, 1931) deeper parts of the shelf, whereas C. campanulaeformis (Eisenack, 1931) is more widespread. Representatives of the genus Cyathochitina appear to be absent in most of the near-shore environment. However, these chitinozoan biofacies are probably of only regional significance and occur where calcareous muds (which formed calcilutites) were deposited.
\end{abstract}

Key words: Chitinozoa, Llandovery, biofacies, East Baltic.

\section{INTRODUCTION}

Calcareous muds were deposited over an extensive area of the northern and central-eastern Baltic at the end of early Llandovery (Coronograptus cyphus) time. The calcilutites which formed of these muds are currently included in the Slitere Member of the Saarde Formation (Gailite et al., 1987) and partly in the Nurmekund Formation of the Raikküla Regional Stage (Nestor, 1995). The presence of skeletal detritus in limestones determines the Raikküla Formation (Fig. 1). The more argillaceous basal strata of the Raikküla Stage are, in some sections, considered to be a separate member, the Pusku Member (Heldur Nestor, pers. comm.). Within the wide deposition area of these limy sediments, mineralogical and palaeontological differences and structural features indicate various sedimentary environments (Jürgenson, 1966; Kaljo \& Jürgenson, 1977; 


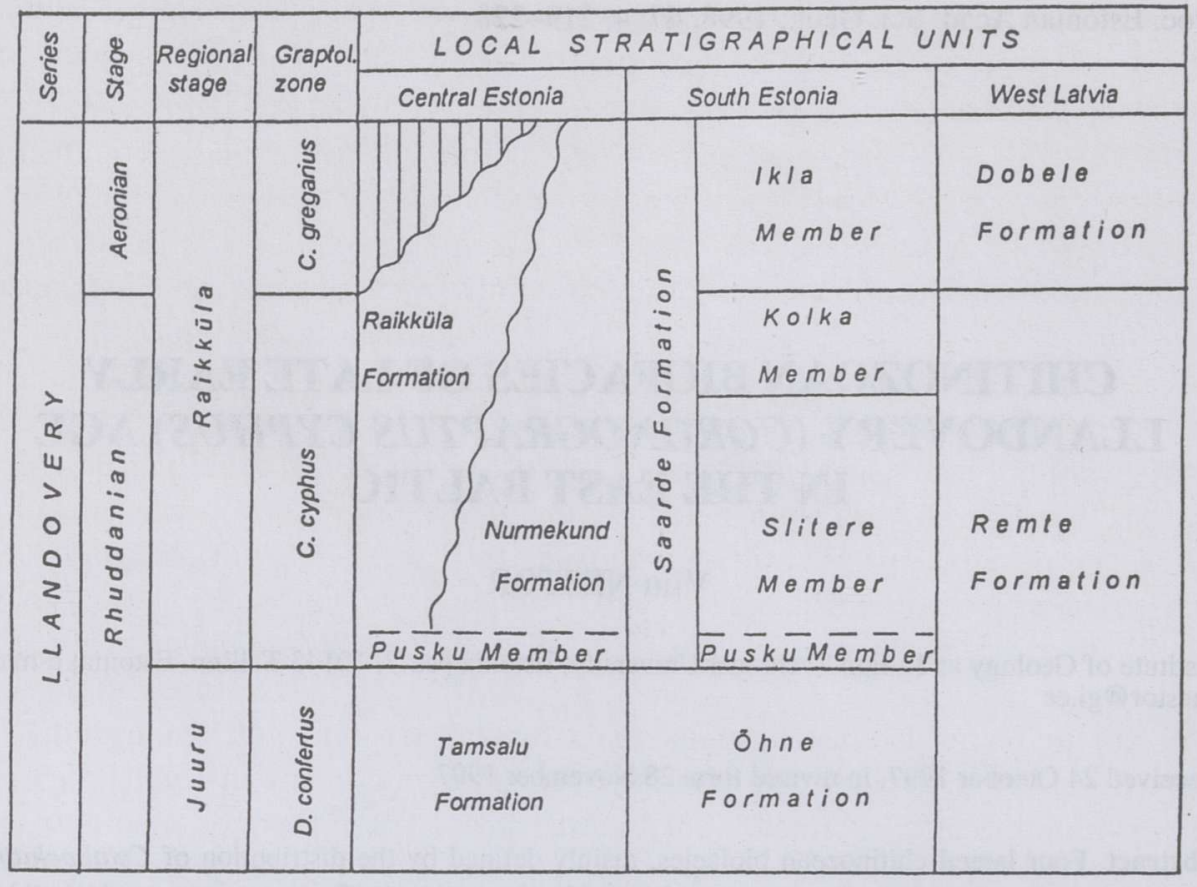

Fig. 1. Stratigraphic correlations and generalized nomenclature of the uppermost lower Llandovery units of the East Baltic (after Nestor, 1995).

Einasto, 1986). Organic remains are rare in the calcilutites, and palaeontological information comes mainly from specific fossiliferous beds. The intercalation of graptolitic mudstones in the limestones indicates more offshore conditions, and the presence of algal structures suggests shallower conditions of sedimentation. The content of fine terrigenous material decreases shoreward - to the north and east of Estonia where coarse-grained limestones, dolomicrites, and dolomites occur. In addition, the distribution of brachiopod communities in the Raikküla Stage, studied by Kaljo \& Rubel (1982), shows their distinct connection to lithofacies belts. Thus, in the northernmost core sections (e.g. Kirikuküla), the Linoporella and Borealis communities occur, and in central Estonian cores (e.g. Varbla and Sulustvere) the Pentamerus and Stricklandia communities are represented. In southwest Estonian and north Latvian core sections (e.g. Ohesaare, Ikla, and Kolka), the Clorinda community is present.

Kaljo \& Vingisaar (1969), Kaljo (1970), and Ulst (1973) correlated limestones of the Slitere (earlier Sturi) Member with strata of the lower and middle parts of the Coronograptus cyphus Zone. The thickness of the Slitere Member ranges from 6 to $36 \mathrm{~m}$ in central and southern Estonia and northern Latvia. During cyphus time, deeper-water argillaceous sediments of the Remte Formation deposited in western Latvia. 
In southern Estonian and northern Latvian sections (Fig. 1), the Slitere Member is overlain by argillaceous limestones and marls of the Kolka Member. In central Estonia this part of the sequence (included in the Raikküla Formation) comprises shallow-water near-shore deposits (facies belts I and II of Nestor \& Einasto, 1977) which are barren of chitinozoans. This upper part of the sequence which is of late $C$. cyphus age is not considered in the present paper.

\section{CHITINOZOAN DISTRIBUTION}

The presence of the late early Llandovery Conochitina electa chitinozoan Biozone has been established in nearly all Estonian and Latvian sections studied (Nestor, 1994). Graptolite data from the Ikla, Kolka, and Ventspils core sections (Kaljo, 1970; Ulst, 1973; Gailite et al., 1987) indicate that the Conochitina electa Zone is correlative with the Coronograptus cyphus Zone.

This paper discusses the chitinozoan biofacies in the lower half of the Conochitina electa Zone which is characterized by the appearance of numerous specimens of Conochitina electa Nestor, 1980 in the lowermost part of the Raikküla Stage, up to a small "interregnum" within the Conochitina electa Zone, indicated by the scarcity or absence of chitinozoans (Nestor, 1994). The lower boundary of this zone is defined, apart from abundant appearance of Conochitina electa, also by the disappearance of Belonechitina postrobusta (Nestor, 1980) and Cyathochitina kuckersiana (Eisenack, 1934). The last mentioned species are common in the uppermost beds of the Juuru Stage (Fig. 1), which are correlated, using graptolites, with the Dimorphograptus confertus Zone (Kaljo et al., 1984). However, Cyathochitina kuckersiana may also occur above the chitinozoan small interregnum within the upper part of the Kolka Member whereafter this species disappears.

The distribution of chitinozoan species, except Ancyrochitina ancyrea (Eisenack, 1931), is shown in Fig. 2 for selected sections which have different facies character. Figure 3 displays the regional distribution of certain, more abundant, chitinozoan species occurring in the lower part of the Raikküla Stage. Each bar represents the approximate range of the species in the interval studied in the corresponding section. Conochitina electa (Pl. I, figs. 1-3) is present in all sections (Fig. 3), whereas other species occur irregularly. The distribution of Ancyrochitina species is not shown in Fig. 3, but A. ancyrea (Pl. II, fig. 6) is found in all sections; A. bifurcaspina Nestor, 1994 (Pl. II, fig. 3) occurs mostly in the lower part of the studied interval, but sometimes sporadically throughout the section; Plectochitina cf. P. spongiosa (Achab, 1977) (PI. II, fig. 4) is distributed in the Viki, Kolka, and Asuküla cores; Ancyrochitina ramosaspina Nestor, 1994 (Pl. II, fig. 5) occurs in the uppermost part of the studied interval in the Ohesaare, Ruhnu, Ikla, Varbla, and Viki cores; and sparse Belonechitina aspera (Nestor, 1980) are identified in the Ruhnu, Sulustvere, Asuküla, and Raikküla cores. 


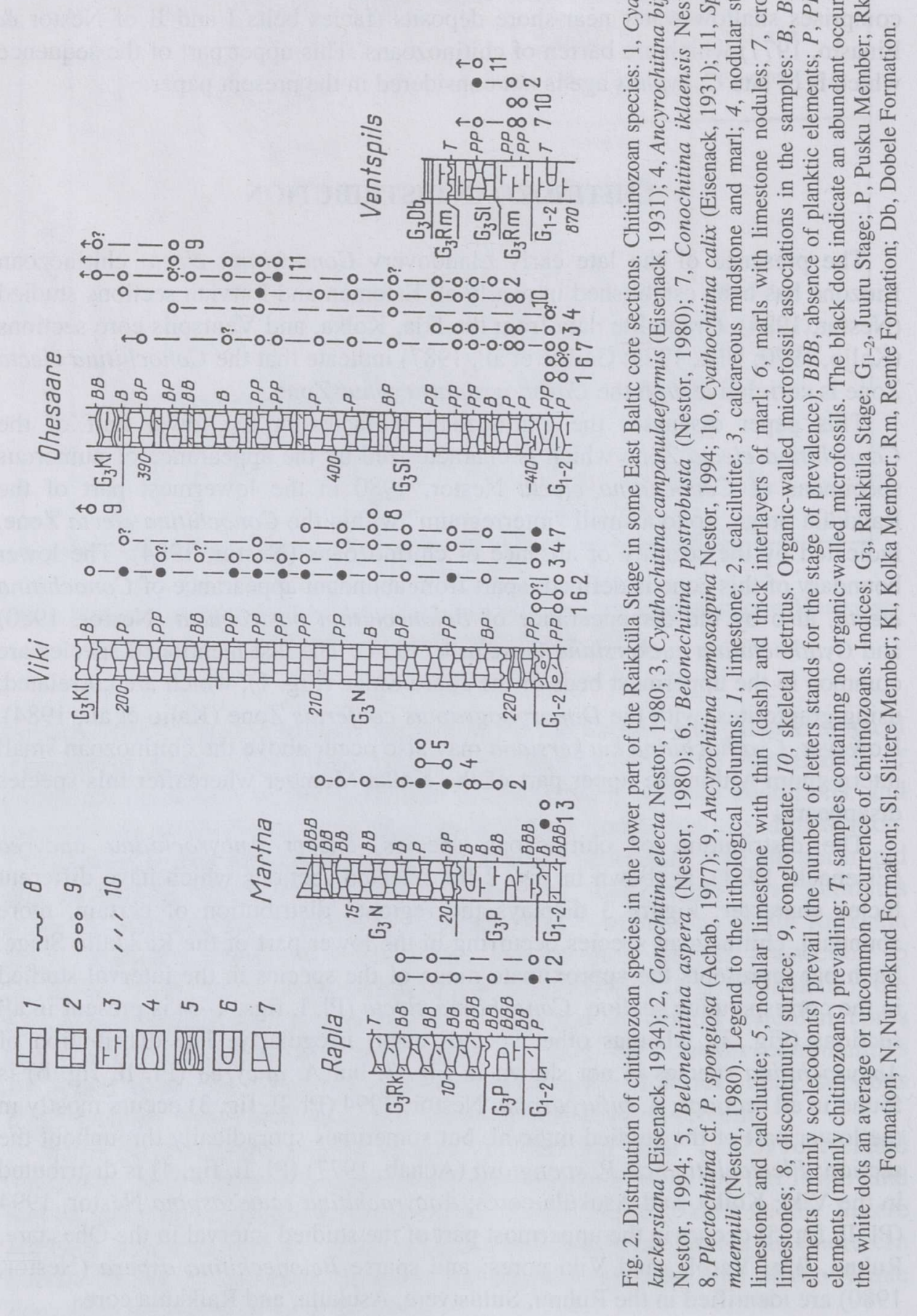

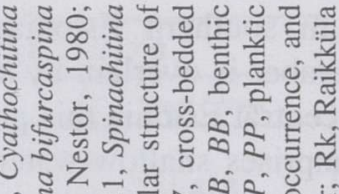

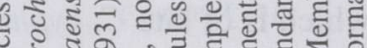

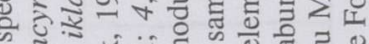

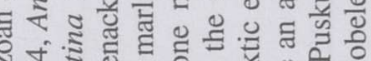

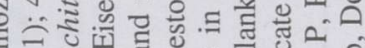

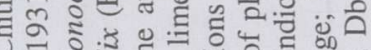

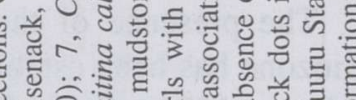

त्व

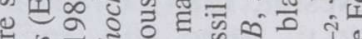

इ ฮै 6000

อे 의

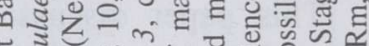

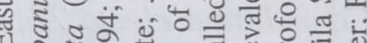

0 ミ气

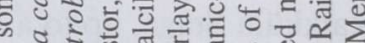

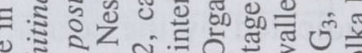

I ๘

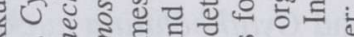
ต

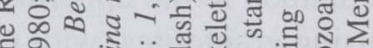

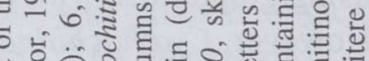

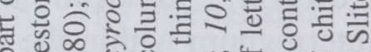

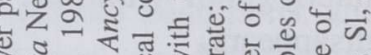

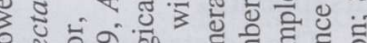
ป

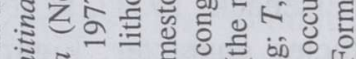

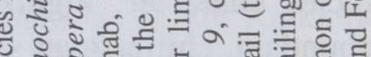

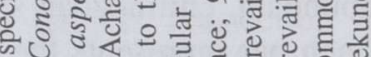

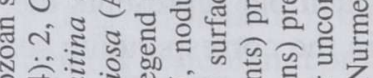
券

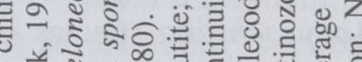

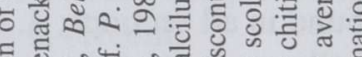

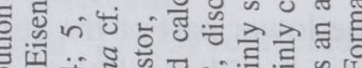

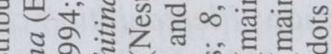
कิ

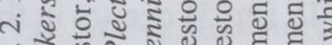
它造 


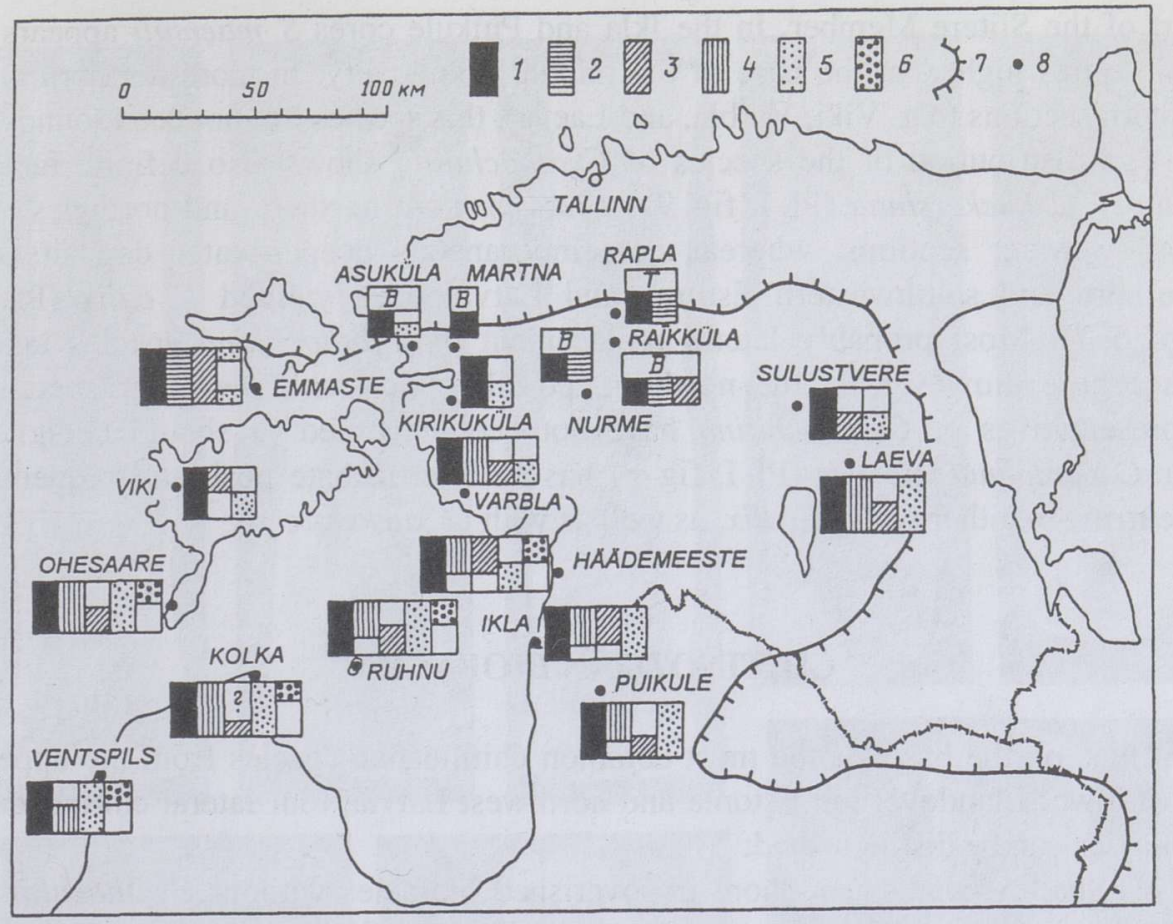

Fig. 3. Distribution pattern of selected chitinozoan species in the lower part of the Raikküla Stage in the sections studied. White blocks indicate the interval of the section where a particular species does not occur. 1, Conochitina electa Nestor, 1980; 2, Cyathochitina kuckersiana (Eisenack, 1934); 3, Cyathochitina campanulaeformis (Eisenack, 1931); 4, Cyathochitina calix (Eisenack, 1931); 5, Conochitina iklaensis Nestor, 1980; 6, Spinachitina maennili (Nestor, 1980); 7, limit of the present distribution of the lower Llandovery deposits; 8 , location of the core sections. $T$, part of the section containing no organic-walled microfossils; $B$, part of the section containing only benthic microfossils (mainly scolecodonts).

These forms do not appear to show any environmental control, except for the extreme rarity of specimens of Ancyrochitina in the deepest-water sediments of the Ventspils section.

The dominant species in all studied sections is Conochitina electa, suggesting a broad tolerance to different environmental conditions.

Conochitina iklaensis Nestor, 1980 (Pl. I, figs. 4, 5) is common in the southern and southwestern cores, but in central Estonia it is missing or occurs only in the lowermost part of the interval considered (Fig. 3).

Spinachitina maennili (Nestor, 1980) (Pl. II, figs. 1,2) is present only in the sections of southwest Estonia. This species is characteristic of the middle Llandovery (Nestor, 1976, 1980, 1994), but appears already in the uppermost 
part of the Slitere Member. In the Ikla and Puikule cores S. maennili appears a few metres higher, at the base of the middle Llandovery. In more northern and eastern sections (e.g. Viki, Varbla, and Laeva), this species has not been found.

The distribution of the species of Cyathochitina shows also definite facies control. C. kuckersiana (PI. I, fig. 9) occurs in more northern and northwestern shallow-water sections, whereas contemporaneous deeper-water deposits of southern and southwestern Estonia and Latvia have yielded C. calix (PI. I, figs. 6,7). Most probably lateral replacement of Cyathochitina species takes place here, however, in the northern, possibly most shallow-water sections representatives of Cyathochitina have not been recorded. It should be noted that $C$. campanulaeformis (PI. I, fig. 8) has an intermediate position, frequently occurring together with $C$. calix, as well as with $C$. kuckersiana.

\section{CHITINOZOAN BIOFACIES}

Thus, on the basis of the most common chitinozoan species from the uppermost lower Llandovery in Estonia and northwest Latvia, four lateral chitinozoan biofacies can be distinguished:

(1) Shallow-water near-shore impoverished biofacies without Cyathochitina. It occurs in the northwesternmost part of Estonia (Kirikuküla, Asuküla, and Martna cores; see Fig. 3).

(2) Shallow-water biofacies with Cyathochitina kuckersiana. Conochitina iklaensis is usually missing. This biofacies occurs in the northern, central part of Estonia (Nurme, Rapla, and Raikküla cores).

(3) Biofacies with Cyathochitina campanulaeformis. In the lower part of the studied interval Conochitina iklaensis is also present. The biofacies is distributed in the western and eastern parts of central Estonia (Sulustvere, Viki, and Emmaste? cores).

\section{PLATE I}

Figs. 1-3. Conochitina electa Nestor, 1980; Raikküla Stage. 1, Ch 30/1220, Emmaste core, depth $41.3 \mathrm{~m}, \mathrm{SEM} \times 250.2$, Ch 36/9388, Ventspils core, depth $867 \mathrm{~m}, \mathrm{SEM} \times 250.3$, Ch 28/1220, Emmaste core, depth $41.3 \mathrm{~m}, \mathrm{SEM} \times 250$.

Figs. 4, 5. Conochitina iklaensis Nestor, 1980; Raikküla Stage, Ruhnu core, depth 584 m, SEM $\times 250.4$, Ch 37/1682; 5, Ch 40/1682.

Figs. 6, 7. Cyathochitina calix (Eisenack, 1931); Raikküla Stage. 6, Ch 429/1685, Ruhnu core, depth $576.2 \mathrm{~m}, \mathrm{SEM} \times 250.7$, Ch 42/611, Ohesaare core, depth $399 \mathrm{~m}, \mathrm{SEM} \times 250$.

Fig. 8. Cyathochitina campanulaeformis (Eisenack, 1931). Ch 43/9540, Juuru Stage, Seliste core, depth $340.3 \mathrm{~m}, \mathrm{SEM} \times 250$.

Fig. 9. Cyathochitina kuckersiana (Eisenack, 1934). Ch 431/1367, Raikküla Stage, Varbla core, depth 189.85 m. 9a: SEM $\times 250$; 9 b: detail (carina), SEM $\times 250$. 

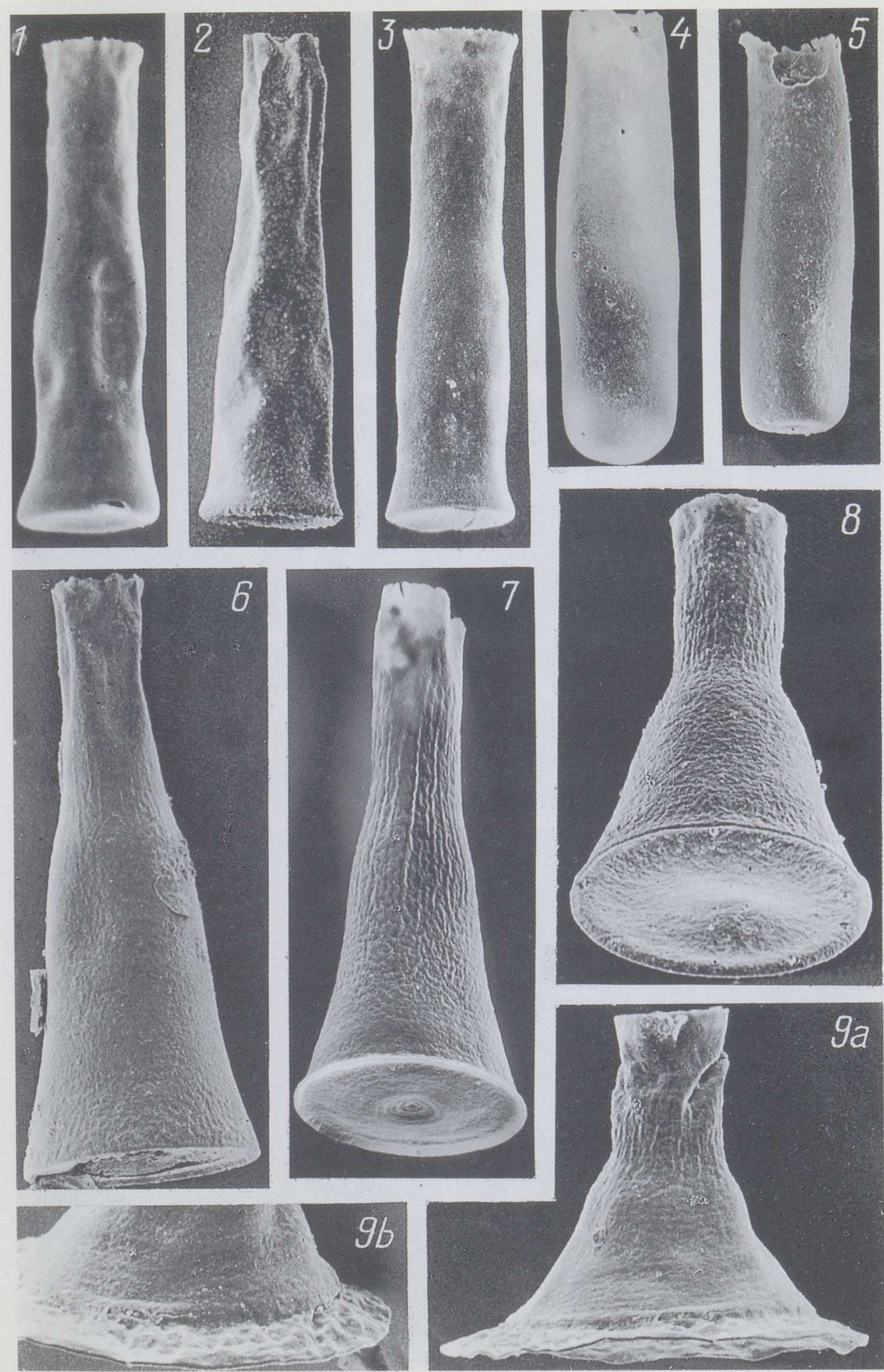

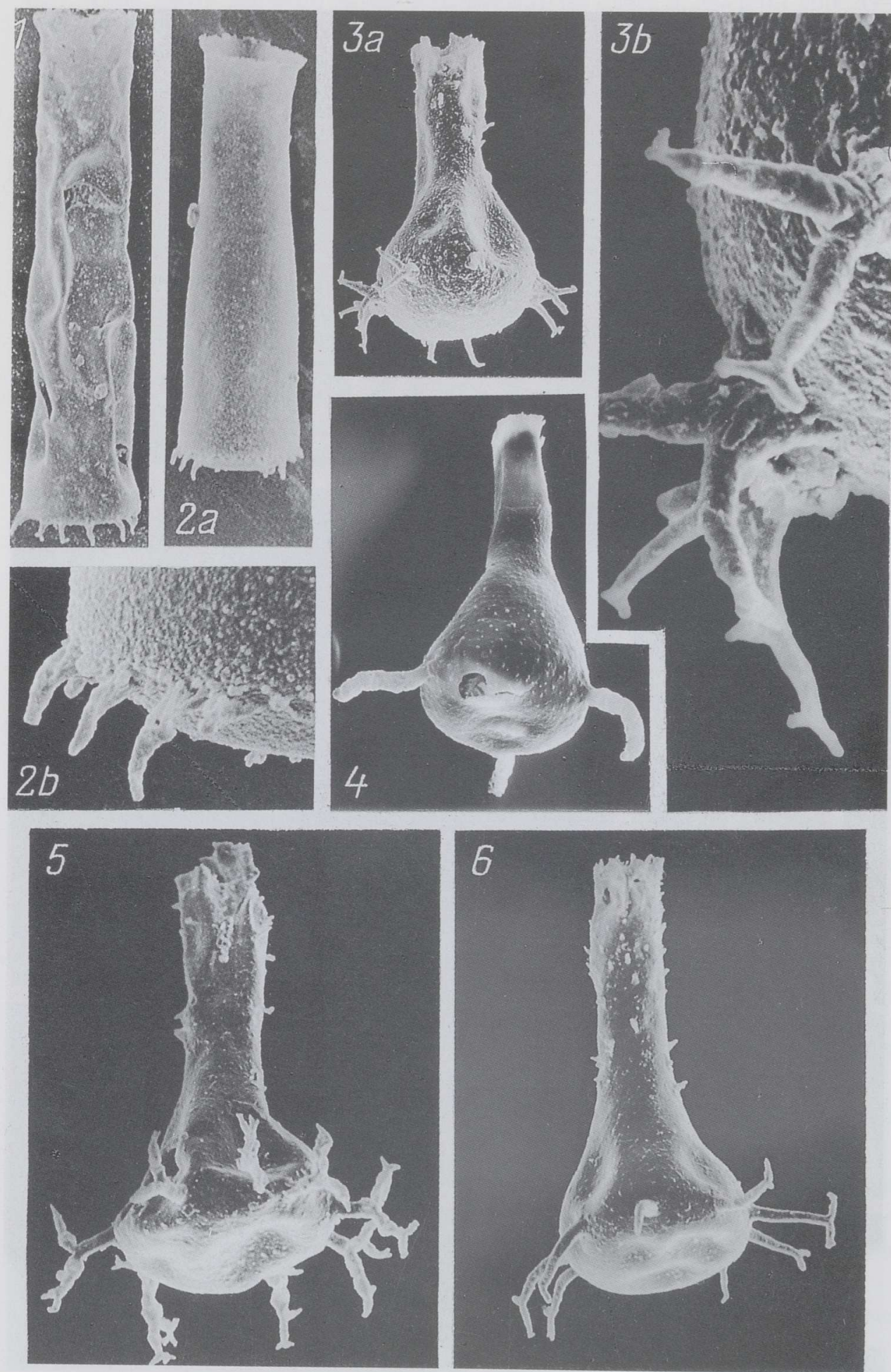
(4) Deep-water offshore biofacies with Cyathochitina calix. Numerous specimens of Conochitina iklaensis and rare Cyathochitina campanulaeformis are recorded as well. This biofacies is restricted to the southern and southwestern parts of Estonia and northwest Latvia.

Considering the presence or absence of Spinachitina maennili in the latter biofacies, the following depth controlled variations as subdivisions can be distinguished:

(a) Spinachitina maennili is missing, also in the middle Llandovery (Varbla and Laeva cores; see Nestor, 1994).

(b) Spinachitina maennili is missing, but appears higher in the section in the lowermost middle Llandovery (Ikla and Puikule cores).

(c) Spinachitina maennili appears already in the upper part of the lower Llandovery - in the middle of the Slitere Member (Ohesaare, Ruhnu, Häädemeeste, Kolka, and Ventspils cores).

In deeper-water settings Cyathochitina is rare or disappears, suggesting some environmental control. In the Ventspils core, C. calix occurs only in the lowermost part of the condensed sequence.

According to the facies model for the East Baltic Silurian (Nestor \& Einasto, 1977, 1982), the first three chitinozoan biofacies (1-3) are of shelf origin, whereas 1-2 are characteristic of the inner (shallow) shelf, and 3 of the middle (deeper) part of the shelf. The deepest biofacies with C. calix (4) is mainly restricted to the outer shelf (transition facies belt).

This distribution model of chitinozoans in different facies belts is now considered valid only in case of sedimentation of very fine-grained calcareous muds which form calcilutites. In the underlying, topmost part of the Juuru Stage, as well as in the overlying, topmost part of the Kolka Member, in the argillaceous nodular limestones and marls, no differences were observed in the distribution pattern of Cyathochitina species. Cyathochitina kuckersiana occurs in large numbers in shallow-water sections of the Tamsalu Formation in central Estonia, as well as in the deeper-water Õhne Formation and Kolka Member of the Saarde Formation in southern Estonia.

\section{PLATE II}

Figs. 1, 2. Spinachitina maennili (Nestor, 1980); Raikküla Stage. 1, Ch 2/1462, Ikla core, depth $462.9 \mathrm{~m}, \mathrm{SEM} \times 250.2$, Ch 1/1686, Ruhnu core, depth $573.3 \mathrm{~m} .2 \mathrm{a}: \mathrm{SEM} \times 250 ; 2 \mathrm{~b}: \mathrm{SEM} \times 1360$.

Fig. 3. Ancyrochitina bifurcaspina Nestor, 1994. Ch 541/1919, Raikküla Stage, Ohesaare core, depth 391.35 m. 3 a: SEM $\times 525 ; 3$ b: SEM $\times 1630$.

Fig. 4. Plectochitina cf. P. spongiosa (Achab, 1977). Ch 46/9798, Raikküla Stage, Kolka core, depth $640.8 \mathrm{~m}, \mathrm{SEM} \times 350$.

Fig. 5. Ancyrochitina ramosaspina Nestor, 1994. Ch 252/1452, Raikküla Stage, Ikla core, depth $480.4 \mathrm{~m}, \mathrm{SEM} \times 320$.

Fig. 6. Ancyrochitina ancyrea (Eisenack, 1931). Ch 241/1919, Raikküla Stage, Ohesaare core, depth $391.35 \mathrm{~m}, \mathrm{SEM} \times 350$. 
Wood, G. D. 1974. Chitinozoa of the Silica Formation (Middle Devonian, Ohio): Vesicle ornamentation and paleoecology. Publications of the Museum. Michigan State University, Paleontological Series, 1, 4, 127-162.

Wright, R. P. 1978. Biogeography of Middle Devonian Chitinozoa of the Midwestern United States. Palinologia Numero Extraordinario, 1, 501-505.

\section{KITINOSOADE BIOFAATSIESED IDA-BALTI VARA-LLANDOVERY LÕPUS (CORONOGRAPTUS CYPHUS'E EAL)}

\section{Viiu NESTOR}

Kitinosoade, põhiliselt Cyathochitina liikide leviku alusel saab Ida-Balti Alam-Llandovery läbilõigetes eristada nelja lateraalset biofaatsiest. C. kuckersiana (Eisenack, 1934) näib eelistavat rannalähedasi madalaveelisi olusid ja C. calix (Eisenack, 1931) šelfi sügavaimat osa, kuna C. campanulaeformis (Eisenack, 1931) on laiema levikuga. Perekond Cyathochitina esindajate puudumine kõige põhjapoolsemates läbilõigetes tähistab omaette, vaesustunud biofaatsiest. Need biofaatsiesed on tõenäoliselt siiski vaid regionaalse tähtsusega ja on seotud põhiliselt puhaste lubimudade (neist on hiljem kujunenud afaniitsed lubjakivid) settimisega.

\section{БИОФАЦИИ ХИТИНОЗОЙ В ВОСТОЧНОЙ ПРИБАЛТИКЕ В КОНЩЕ РАННЕГО ЛЛАНДОВЕРИ (BPEMЯ CORONOGRAPTUS CYPHUS)}

\section{Вийу НЕСТОР}

По распространению хитинозой, в основном видов Cyathochitina, в ряде разрезов нижнего лландовери Восточной Прибалтики выделены четыре латеральные биофации. C. kuckersiana (Eisenack, 1934) встречается в северных и северо-западных разрезах, предпочитая более мелководные прибрежные условия, C. calix (Eisenack, 1931) - в разрезах Южной и ЮгоЗападной Эстонии и Латвии, выбирая средой своего обитания более глубоководные участки шельфа, и C. campanulaeformis (Eisenack, 1931) занимает промежуточное между ними положение. Отсутствие представителей семейства Cyathochitina в самых северных разрезах позволяет выделить отдельную, четвертую биофацию. Все эти биофации имеют, по всей вероятности, лишь региональное значение и связаны только с отложениями чистых известковых илов (из которых позднее сформировались афанитовые известняки). 